\title{
TRIALS FOR FUNGAL DECONTAMINATION ON SHEEP CARCASSES
}

\author{
Elgazzar M. M. M. \\ Food Hyglene and Control Dept.- Fac. Vet. Med.. \\ Mansoura Unlversity. Egypt
}

\begin{abstract}
The fungal contamination onto the outside (subcutaneous) surface of 20 sheep carcasses, slaughtered and dressed at Mansoura municipal fold-fashioned) abattoir. was anailyzed before and after 5 different decontamination triats tiwo at the abattoir and three at the laboratory). At abattoir. this coniamination was surveyed over the round. Jank, shoulder, and neck surfaces each of 10 carcasses before and afler abaltoir decontamination trials, whereas, at laboratory the same mycological analysts was carried out on the surface of abdominal flap. freshly excised from every of other 10 sheep carcasses before and after laboratory decontaminatton trials.

The presence of yeast and moutd contamination was detected in all triple-suab samples taken from the examured surfaces before decontamination trials (100\%). After application of the first abattolr triat, the presence eveny of yeast and mould contamination was recognized in $80-100 \%$ of round. flank, shoutder, and neck samples of car. cass surfaces hose-sprayed with tap water for one minute, while the second abattoir decontamination trial could decrease the yeast contaminated sampies $1050-80 \%$, and mould-contaminated samples to 70 - 9096 over the same carcass surfaces inse. sprayed with tap water for one minute then wiped with steritized cloth untl removal most of ulsible dirts. Yeast and mould contaminalton were also delected in 40 and $50 \%$ samples of abdominal flap surfaces sprayed with $0.27 \%$ benzoic acid solution for one minute first laboratory decontamination trial). in 50 and $80 \%$ samples of abdontual fap surfaces sprayed with $2 \%$ acetic acid solution for one minule (second laboratory decontamination trial), and in $80 \%$ samples (eacly of abdominal jlap surfaces sprayed wth $2.5 \%$ potasstum sorbate solution for one minute (third laboratory decontamination triall, respectively.
\end{abstract}

The mean levels of yeast and moutd intensities onto the untreated carcass surfaces. sampled at abattoir, were $90.5 \& 116.69 .01 \& 79.23 .152 \& 94.5$. and $192.5 \& 101.9$ 
propagules $/ \mathrm{cm} 2$ of round. flank, shoulder, and neck sùrfaces reduloudilo. 51.07 \& $44.05,32.05 \& 43.01,60.09 \& 47.95$. and $58.21 \& 67.86$ propagules/cm2 with corresponding reduction percentages of $55.72 \& 43.57 \% .53 .56 \& 45.72 \% .60 .47 \& 49.26 \%$. and 69.76 \& $33.41 \%$ onto the same surfaces after hose-spraying each of them with tap water for one minute. while these leveis further decreased to 28.16 \& 27.10. 11.20 \&: $31.0,10.08 \& 30.85$, and 20.19 \& 50.07 propagules $/ \mathrm{cm} 2$ with synonymous decrease percentages of 85.46 \& $68.88 \%, 83.77$ \& $60.87 \%, 93.37 \& 67.35 \%$. and 89.51 \& $50.86 \%$ on these surfaces, consecutively afler hose-spraying each of them with lap water for one minute followed by wiping with sterilized cloth. Furthermore, the inllial mean values of yeast and mould population over the untreated abdominal flap surfaces, sampled at laboratory. were 70.28 \& 49.06 propagules/cm2 decreased $1016.99 \&$ 28.08 propagules $/ \mathrm{cm} 2$ after spraying each of them with $0.27 \%$ benzoic acid solution for one minute, to $18.03 \& 26.01$ propagules/ $\mathrm{cm} 2$, and to $26.91 \& 23.0$ propagules/ $\mathrm{cm} 2$ after an independent spraying each of them with $2 \%$ acetic acid and $2.5 \%$ potas. sium sorbate solutions for one minute with corresponding decline percentages of 75.83 \& $42.76 \%, 74.35 \& 46.98 \%$, and $61.71 \& 53.12 \%$. successively.

A total of identified 619 (100\%) mould strains. belonged to 20 genera, could be iso. lated from all surveyed samples and distributed as 109 (17.61\%) Penicillium, 104 (16.80\%) Aspergillus, 74 (11.95\%) Cladosporium, 53 (8.56\%) Allemaria, and 51 (8.24\%) Moniliella strains at the top. followed by 26 (4.2\%) Humicola. 24 (3.88\%) Geotrichum candidum. 23 (3.72\%) Fusarium. 22 (3.55\%) Absidia, 20 (3.23\%) Syncephalastrum. and 19 (3.07\%) Acremonium strictum strains, together with 16 (2.58\%) Stemphylium, 13 (2.1\%) Mucor, 12 (1.94\%) each of Aureobasidium and Paecllomyces. 9 (1.45\%) every of Scopulariopsis and Trichoderma. 8 (1.29\%) each of Rhizopus and Botrytis, alongside 7 (1.13\%) Thamnidium strains. The obtained 104 (100\%) Aspergillus strains further char. acterized into 11 groups as 42 (40.38\%) A. niger. 23 (22.12\%) A. flavus, and 9 (8.65\%) A. fumigatus strains at the top. followed by $7(6.739)$ A. amstelodami and A. candid. us, 5 (4.81\%) every of A. sydowii and A. ochraceus, 2 (1.92\%) each of $A$. clavatus and A. nidulans, together with one strain (0.96\%) every of $A$. chevalieri and $A$. wentii.

\section{INTRODUCTION}

Sheep were probably among the first animals to be domesticated by man for mutton. milk. and wool production. In Egypt, lambs provide the most important meat for making fried "kofta"and Kabob. hence they are usually slaughtered at $36-45 \mathrm{~kg}$ live welght with a resultant 17-23 
kg dressed carcass. However, mutton can also denved from gimmers, ewes, wethers, and rams.

The healthy inner flesh of dressed sheep carcasses has been reported to contain few or no microorganisms, although they have been found in lymph nodes. bone marrow, and even flesh. The important contamination, however, comes from the external sources during bleeding. handling. and dressing. During bleeding, skinning, and evisceration, the main sources of microorganisms Including fungl are the exterior of animal (skin, wool, and hooves) alongside the gastrointestinal tract. The exterior of animal harbors large numbers and many kinds of fungi particularly moulds derived from soll, water, feed, and manure besides its natural surface flora (Batista et al., 1961; Klare, 1970; Nakae et al., 1976: Ayres et al., 1980; Ramirez, 1982; Farghaly, 1985; and Rosenzweig et al., 1986). Knlves, cloths, abattolr environment (floor, walls, alr, and water of slaughter halls), in addition to hands and clothing of the workers can serve as intermediate sources of these contaminants (Refal and Loot, 1969; Mansour, 1986; Eldaly et al., 1988; Yassien et al., 1989; Hamdy et al., 1991; and Ismall et al., 1995).

There is no fungus - free environment in our life (Chao et al., 2002). Therefore, the sheep carcasses during their dressing can be contaminated with fungal propagules from the surroundIng environments. So, moulds of many genera could reach the meat surfaces and grow there: Penicillum, Aspergillus, Cladosporlum, Geotrichum, Mucor, Fusarlum, Alternaria, and Thamnidium are prevalent species (Ayres et al., 1980). Nature and extent of fungal contamination on dressed sheep carcasses are important criterla in judging their hygienic quality (Samson et al., 1981). The mycological condition of carcasses is very dependent on the conditions under which their animals are reared, slaughtered, and dressed.

Along with moulds, yeasts belong to the class Mycota or fungi, which are primitive plant-like structures lacking in chlorophyll. The yeasts are microscopic. single-celled organisms generally larger than the bacteria. Yeasts are mostly saprophytic, while few species are pathogenfc. They occur almost everywhere in the environment as well as on skin and in alimentary tract of mammals. A mould consists of a mycellum of branched flaments (hyphae) which bear spores or conidia. In contrast to the yeasts, moulds can be seen with the naked eye as fluffy growths on meats; coloured black, white, or other pigments. Like yeasts, they are primarily saprophytic organisms, breaking down complex organic materials into simpler substances, thus contributing to the decomposition of meats (Gracey and Collins, 1992).

Meat provides an ideal medium for fungal growth. as It has an optimal pH range (5.6-6.7). A high water content (aw $=0.99$ ), a rich supply of nitrogenous substance, and a source of carbohy. drate. Meat may assume a mouldy odour and taste if the mould affection is extensive. and for long standing the fat rancidity may occur (Jay, 1992). Furthermore, most of moulds can deterio- 
rate meat through production of their proteolytic and lipolytic enzymes (Ayres et al., 1980). Some moulds can also elaborate toxic substances (mycotoxins) in infected meats that are polsonous for man (Bullerman et al., 1969a\&b). So. the mould growth on meat causes an econoinIc loss caused by trimming of the affected parts (Welser, 1962).

Moulds and yeasts could grow on lamb and mutton carcasses stored at $-5^{\circ} \mathrm{C}$. The mould genera of Penicillium and Cladosporlum attack and penetrate the superficlal layers of connective lissues or fat covering the musculature and produce discolouring spots ranging from yellow to black. Mycelia of vartous members of the Mucoralis may also observed onto these carcasses. wherein strains of Thamnidium, Mucor, and Rhizopus can produce an extensive whiskery, or cottony grey- to- black growth (Ayres et al., 1980). On the other hand, yeasts seldom cause spollage of fresh red meats, being only a small part of the initial microbial population and growing more slowly than most bacteria. Yeasts cause spoilage of refrigerated meats only when bactcrial numbers have been restrtcted (Ayres et al., 1980). Spollage of chllled beef $\left(a t-1,1^{\circ} \mathrm{C}\right.$ ) is caused by growth of a mixture of bacteria, yeasts, and moulds on the beef surface (Empey and Scott, 1939). In general, yeasts can grow on much dryer surfaces than can bacteria. The characteristic yeasty odour is mostly pronounced in the affected meats.

The fungal contamination over cattle and sheep carcasses was evaluated by many researchers (Eldaly et al., 1988; Yassien et al., 1989; Elgazzax, 1992; and Shabanh, 1995). however they did not try to inhibit or reduce such inevitable contamination. Meat hyglene alms at reducing contamination and preventing the prollferation of harmful mycoflora. Hence. one minute hosespraying of the whole surface of freshly dressed carcasses at abattoirs with a tap water. elther exclusively or followed by wiping with sterilized cloth until removal most of visible clirts, are probable successful trials for decontamination (Mohammed, 2004). In addition to the trend of the use of some chemicals including organic acids to prevent or dekij the meat spoilage has been practiced 5000 B. C. (Luek, 1980). Propionic, sorbic, benzolc, acetic. formic acids and thelr salts recelved much interest in the last decade as fungal decontaminators in/on food (Farkas, 2001).

The alm of the present work. therefore, was to evaluate the mycological condition of the firesh. ly dressed sheep carcasses at Mansoura municipal (old-fashtoned) abattoir alongside the creation of some applicable fungal decontamination trials, through fulfiling these points:

I. Estimation of both yeast and mould populations per each square centimeter of the outside surface of freshly dressed sheep carcasses, before and after decontamination trials.

II. Generic Identufication of the Isolated mould strains with further group charactertzation of the obtalned aspergilli.

Mansoura, Vet. Med. J.

Vol. VI. No. 1, 2005 
III. Evaluation of the efficacy of different 5 fungal decontamination trials onto the tested carcass surfaces; (1) hose-spraying of the whole carcass surface with a nunicipal (tap) water for one minute. (2) hose-spraying of the whole carcass surface with a municipal water for one minute, followed by wiping with a sterilized cloth until removal most of visible dirts. (3) spraying of a limited outside surface area of the abdominal flap (about $10 \times 10 \mathrm{~cm}$ ). freshly excised from dressed untreated sheep carcass, with $0.27 \%$ benzolc acid solution for one minute. (4) spraying of a limited outside surface area of the abdominal nap (about $10 \times 10$ $\mathrm{cm}$, recently excised from dressed untreated sheep carcass, with $2 \%$ acetic acid solution for one minute, and (5) spraying of a limited outside surface area of the abdominal flap (about $10 \times 10 \mathrm{~cm}$ ). freshly excised from dressed untreated shcep carcass with $2.5 \%$ potasslum sorbate solution for one minute.

\section{MATERLAL AND METHODS}

\section{COLLECTION AND PREPARATION OF THE SAMPLES :}

The outside (subcutaneous) surface of different sites of 20 sheep carcasses. siaughtered and dressed at Mansoura municipal (old-fashioned) abattolr, was swabbed and tested mycologically. before and after 5 various decontamination treatments. All sampled carcasses were from animals had unclean fleece and processed under similar conditions, where they have been slaughtered by Islamic method after being lain on a dirty floor, through severing both carotid arteries and jugular veins, trachea, besides oesophagus then left 2 minutes for effictent bleeding followed by floor-dressing.

Out of the examined carcasses. the outside surface each of round, fank. shoulder, and neck of 10 carcasses was alternatively sampled 3 tumes at the abattolr: every ime represented one of the three carcass conditions: (1) Immediately after skinning and evisceration "without rinsing or any decontamination treatment". (2) after a continuous hose-spraying of the whole carcass surface with a munlclpal (tap) water for one minute fat a maximal pressure without splashing of the neighboring carcasses), and (3) after a contInuous hose-spraying of the whole carcass surface with a tap water for one minute followed by wiping with a sterilized cloth. The latter carcass condition was achteved by wiplng the prevlously hose-sprayed surface until removal most of the visible dirts.

The outside surface of one large abdominal flap, aseptically excised from each of the renainIng 10 untreated carcasses, was also sampled rapidly at the laboratory under 4 different conditions (every condition was revealed onto an independent fap subsample having a linited area of about $10 \times 10 \mathrm{~cm}$ ): (1) shortly after dressing of untreated carcass plus excision and packaging of 
sampled flap "without rinsing or any decontamination treatment". (2) after a continuous sprayIng of the whole outside surface of flap subsample with a $0.27 \%$ benzoic acld solution (maximal solubility) for one minute. (3) after a continuous spraying of the whole outside surface of flap subsample with a $2 \%$ acetic acid solution for one minute, and (4) after a continuous spraying of the whole outside surface of flap subsample with a $2.5 \%$ potasslum sorbate solution for one minute. Each of the treated flap subsample was sprayed with one type of the appljed decontaminatIng solutions, by using a 500-ml plastic sprayer, after being hung and clipped on a sterlized frame made of stainless steel.

A limited area $\left(20 \mathrm{~cm}^{2}\right)$ over each surface sample inside a sterilized metal template $(4 \times 5 \mathrm{~cm})$ was rubbed repeatedly and successively by 3 sterilized gauze-cotton swabs (having a size of about $3.5 \times 1.5 \mathrm{~cm}$ and attached to flat wooden stick of about $10 \mathrm{~cm}$ length): the first swab was moistened with a $0.1 \%$ peptone water (the diluent used) while the other 2 swabs were clry. The 3 swab sticks were broken off below the contaminated handled area into a sterile 100-ml nask containing $40 \mathrm{ml}$ of the used diluent to give an original dilutlon of $1: 2$ after thorough homogenization of the triple swabs (Patterson. 1971). Each swab sample was then marked and subjected to prompt mycological examination.

\section{MYCOLOGICAL TESTS:}

(1) Enumeration of the yeast and mould propagules in the surface samples (King et al., 1979):

One fifth (0.2) $\mathrm{ml}$ amount from the previously prepared original dilution (1:2) was delivered and spread onto the dried surface each of sterlized duplicate plates of dichloran rose bengal chloramphenicol agar (DRCA). The inoculated plates as well as the control one were incubated at $25^{\circ} \mathrm{C}$ for 5 days. The average of yeast and mould colonies were then enumerated over the duplicate plates and the total yeast count $/ \mathrm{cm}^{2}$ plus the total mould count $/ \mathrm{cm}^{2}$ of the tested surface were calculated and recorded. Every mould growth onto a countable plate was picked up and transferred either onto a slope of Czapek yeast extract agar (CYA) (for hydrophlific moulds) or onto a slope of C7apek yeast extract agar with 20\% sucrose (CY20S) (for osmophilic moulds) then incubated at $25^{\circ} \mathrm{C}$ for $1-2$ weeks and subjected for identification.

(2) Identification of the isolated mould strains:

Genertc identification of the obtained mould strains was carried out according to Raper and Thom (1949), Arx (1967), Zycha et al. (1969), Barnett and Hunter (1972), Samson et al. (1976). Schipper (1978), and Pitt and Hocking (1985), whereas group characterization of the 
recovered aspergill1 was completed owing to Raper and Fennell (1965) and Samson (1979).

\section{STATISTICAL ANALYSIS:}

The data obtained in this study were statistically analysed according to the methods described by Snedecor (1971).

\section{DISCUSSION}

Inspection of Table ( 1 ) exhibits the presence of both yeast and mould contamination in all surveyed swab samples (100\%) taken from the untreated carcass surfaces of round, Hank. shoulder, neck, and abdominal flap. This fungal presence decreased to $80 \& 90 \%$ in round and to $90 \%$ each of yeast and mould in shoulder samples. respectively, while the yeast-contaminated flank samples reduced to $90 \%$ after hose-spraying each of their surfaces with tap water for one minute (first abattoir decontamination trial), whereas the occurrence of mould contamination in flank and neck samples as well as the yeasts in neck ones not affected by this decontamination trial as they could be detected in $100 \%$ of these samples. More reductions in yeast-and mouldcontaminated abattoir samples to $50 \& 70 \%, 70 \& 80 \%, 60 \& 80 \%$, and 80 \& $90 \%$ werc established in those samples obtained from round, flank, shoulder, and neck surfaces, successively after hose-spraying each of them with tap water for one minute followed by wiping with sterlized cloth (second abattolr decontamination trial). Furthermore, a considerable decrease in yeastand mould-contamlnated laboratory samples, taken from the abdominal flaps, to $40 \& 50 \%$, respectively was achieved after spraying each of their surfaces with $0.27 \%$ benzoic acid solution for one minute (first laboratory decontamination trial). Similar drastic reduction (50\%) was also detected in yeast-contaminated samples that obtained from the flap surfaces after spraying every of them with $2 \%$ acetic acid solution for one minute (second laboratory decontamination trial). while moderate decrease $(20 \%)$ was only exhibited in mould-contaminated samples recovered from the same treated surfaces. The third laboratory decontamination trial could slightly and equally reduce the number of both yeast-and mould-contaminated samples by $20 \%$ after spraying each of their hap surfaces with $2.5 \%$ potassium sorbate solution for one minute. General vlew on the obtalned results reveals the noticeable reducing effect of the $0.27 \%$ benzolc acid spraying on the occurrence frequency of yeast and mould propagules in tested samples. while both hose-spraying with tap water and spraying with $2.5 \%$ potassium sorbate solution were the least two effective trials. Also, the presence of yeast contamination in swab samples of treated surfaces was smould one. The decreasing effect of abattoir decontamination trials on the yeastand mould-contaminated samples was more appreciable on the round and shoulder surfaces than that on the flank and neck ones. This may be attributed to the more intense fungal con- 
tamination on the latter 2 surface sltes. The detection of fungal contamination in all examined swab samples of untreated carcass surfaces agreed with the findings obtalned by Shabanh (1995) on sheep carcasses besides those results evaluated by Abd-Allah (2005) on beel carcasses. and can be explained by the literature of Empey and Scott (1939) who determined the average yeast and mould numbers in dry soil found on animals by $5 \times 10^{4}$ and $1.2 \times 10^{5}$ propagules/g. In fresh animal faeces by $2 \times 10^{5}$ and $6 \times 10^{4}$ propagules/g, and in rumen content by $1.8 \times 10^{5}$ and $1.6 \times 10^{3}$ propagules/g. consecutively. Furthermore, the transfer of microfloral contamination from skin and gut of the slaughtered animals to the surface of their carcasses during dressing is inevitable even with using a current slaughterhouse technology (Thornton and Gracey, 1974 and Dickson and Anderson, 1992), in addition to the very high fungal population may be get onto the dressed carcasses from the air, dust, and soil Inside slaughter halls (Lacey, 1973; Christensen et al., 1978; McKenzie and Taylor. 1983; H1ll et al., 1984; and Handy et al.. 1991).

Concerning the intensittes of yeast propagules onto the untreated carcass surfaces: they ranged from 21 to $203 / \mathrm{cm}^{2}$ on round, $14-137 / \mathrm{cm}^{2}$ on flank, $33-260 / \mathrm{cm}^{2}$ on shoulder, 47 . $310 / \mathrm{cm}^{2}$ on neck, and $12-250 / \mathrm{cm}^{2}$ on abdominal flap with mean values of $90.5 \pm 18.11$. $69.01 \pm 14.76 .152 \pm 29.08 .192 .5 \pm 39.1$, and $70.28 \pm 18.36 / \mathrm{cm}^{2}$. respectively. The tirst abattolr decontamination trial those-spraying the whole carcass surface with tap water for one minute) could reduce these yeast propagules to $0-138 / \mathrm{cm} 2$ on round. $0-89 / \mathrm{cm}^{2}$ on llank. $0-79$ $/ \mathrm{cm}^{2}$ on shoulder, and $5.99 / \mathrm{cm}^{2}$ on neck with mean levels of $51.07 \pm 10.06 .32 .05 \pm 7.0 .60 .9$ \pm 12.12 , and $58.21 \pm 13.0 / \mathrm{cm}^{2}$, consecutively. The second abattotr decontamination trial (hosespraying the whole carcass surface with tap water for one minute followed by wiping with sterillzed cloth until removal most of visible dirts) induced the highest reduction in yeast contamination on carcass surfaces wherein the range (minimum - maximum) and mean value of the yeast propagules $/ \mathrm{cm}^{2}$ were $0-52$ and $28.16 \pm 4.22$ on round. $0-28$ and $11.2 \pm 2.86$ on flank, $0-19$ and $10.08 \pm 2.66$ on shoulder, besides $0-41$ and $20.19 \_5.26$ on neck surfaces. The three independent laboratory decontamination trials could also decrease the yeast propagules $/ \mathrm{cm}^{2}$ to 0 . 29 and $16.99 \pm 5.0,0-34$ and $18.03 \pm 4.98$, alongside $0-85$ and $26.91 \pm 8.72$ on the abdominal flap surfaces after spraying every of them for one minute with solutions of $0.27 \%$ benzolc acid (first laboratory decontamination tral). $2 \%$ acetic acid (second laboratory decontamination trial), and $2.5 \%$ potassium sorbate (third laboratory decontamination trial). respectively (Table. 2). These data indicate that the תrst abattoir decontamination trial (hose-spraying the whole carcass surface with tap water for one minutel could remove 55.72. 53.56. 60.47, and $69.76 \%$ of yeast contamination from the round, llank. shoulder, and neck surfaces. successively, whereas the furthest reduction levels in yeast contamination resulted from the second abaltoir decontam- 
Ination trial (hose-spraying the whole carcass surface with tap water for one minute foliowed by wiplng with steriltzed cloth until removal most of visible dirts) as 85.46. 83.77, 93.37, and $89.51 \%$ on the round, flank, shoulder, and neck surfaces, consecutively. Reduction in yeast populations onto the surveyed abdominal flap surfaces can also be obtained by percentages of 75.83, 74.35, and $61.71 \%$ after 3 independent laboratory decontamination trials: spraying each of flap surface for one minute with solutions of $0.27 \%$ benzolc acid. $2 \%$ acetic acid. and $2.5 \%$ potassium sorbate, respectively (Table, 4). Moderately lower yeast contamination levels were detected by Abd-Allah (2005) over the untreated beef carcasses (mcan values of $41.43-100$ propagules $/ \mathrm{cm} 2)$, at the contrary, extremely higher yeast populations $\left(4 \times 10^{3}-2 \times 10^{4}\right.$ propagules/ $\mathrm{cm} 2$ ) onto the analogous carcass surfaces were obtained by Eldaly et al. (1988). This variation may be referred to the different abattolr-santtation levels and yeast-enumeration techniques.

In regard to the decontaminating effects of the first abattoir trial, the greatest reduction in yeast population was revealed on the surfaces of neck $(69.76 \%)$ followed by shoulder $(60.47 \%)$. round $(55.72 \%)$, and flank $(53.56 \%)$, consecutively after hose-spraying the whole carcass surface with tap water for one minute (Table, 4). These findings correspond with the reports of Kotula et al. (1974); Notermans et al. (1980); and Siragusa (1995) who emphasized that the spray washing of carcasses significantly reduces their surface microflora. Approximately similar surface yeast reductions $(47.13-77.78 \%)$ were achleved on beef carcasses, slaughtered and dressed at Mansoura municipal abattoir. after similar decontamination trial performed by Abd-Allah (2005). With respect to the efficacy of second abattoir trial for yeast decontamination, the highest yeast reduction (93.87\%) Induced by this trial was detected onto the shoulder succeeded by $89.51 \%$ on neck, $85.46 \%$ on round. and $83.77 \%$ on flank after hose-spraying the whole carcass surface with tap water for one minute followed by wiping with sterilized cloth untll removal most of visible dirts (Table, 4). These results are analogous to the yeast reductions (82.76-98.61\%) obtained by Abd-Allah (2005) onto the similarly treated beef carcasses. The ultimate yeast decontamination revealed by the second abattolr trial can be attributed to the fact that the spray washing replaces the contaminated water film on carcass surface with a clean water film, thus reducing the microbial load, alongside, the removal most of visible dirts from spray-washed carcass surface with sterlized cloth would additionally enhance the microbial safety of treated carcass meat (Mulder, 1985; Gll, 2004; and Mohammed, 2004).

Regarding the laboratory decontamination trials for decreasing yeast population over the surface of abdominal flaps excised from freshly dressed sheep carcasses, one minute-spraying each of these surfaces with a $0.27 \%$ benzoic acid solution was the most effective trial as could reduce $75.83 \%$ of thetr yeast contamination. followed by the similarly and independently sprayed $2 \%$ acetic acid and $2.5 \%$ potasslum sorbate solutions as could decrease 74.35 and $61.71 \%$ of their 
yeast population. respectively (Table. 4). Higher yeast reduction percentages were obtained by Abd-Allah (2005) after identical benzoic acid tral (96.12\%) and acetic acid trial (94.57\%). whereas analogous yeast reduction level $(60.47 \%)$ resulted after stmilar potasstum sorbate trial onto the surface of beef abdominal flaps. The antimycotic effect of benzoic acid for controlling yeast contamination in/on foods was emphasized by Chistester and Tanner (1972); Luck (1986); and Fraziex and westhoff (1995) besides the inhibitory concentration of benzoic acid against most yeasts was estimated by Chipley (1993) as from 20 to $700 \mathrm{mg} / \mathrm{ml}$. Furthermore, BairdParker (1980) established the capability of acetic acid to reduce microbial population on carcass surfaces through lowering thetr t1ssue $\mathrm{pH}$ and changing permeabilities of microbial cell membrane. The inhibitory effect of potasslum sorbate on the yeast growth and its subsequent Inportance for extending the shelf llfe of beef steaks for 2 days were also reported by Chistester and Tanner (1972); Greer (1982); Bullerman (1985); and Sofos (1989).

Figures arranged in Table (3) show the mould population onto the tested carcass surfaces. before and after decontamination trials; Its range (minimum - maximum) and mean value on the untreated surfaces were $17-204$ and $116 \pm 21.93$ propagules $/ \mathrm{cm}^{2}$ on round, $15-181$ and $79.23 \pm 19.07$ propagules $/ \mathrm{cm}^{2}$ on flank, $20-316$ and $94.5 \pm 21.89$ propagules $/ \mathrm{cm}^{2}$ on shoulder. $33-349$ and $101.9 \pm 22.31$ propagules $/ \mathrm{cm}^{2}$ on neck, together with $14-127$ and $49.06 \pm$ 12.08 propagules $/ \mathrm{cm} 2$ on abdominal flap. The first abattoir decontamination trial decreased these figures considerably to $0-90$ and $44.05 \pm 9.16,9-107$ and $43.01 \pm 9.96 .0-198$ and $47.95 \pm 11.01$. in addition to $24-210$ and $67.86 \pm 16.05$ propagules $/ \mathrm{cm}^{2}$ of the round. flank. shoulder and neck surfaces, respectively after hose-spraying the whole each of their carcasses with tap water for one minute. The second abattoir decontamination trial could induce the ultimate reduction in the level of surface moulds where they ranged from 0 to 63 with a mean of $27.1 \pm 6.98$ propagules $/ \mathrm{cm} 2$ on round. 0.83 and $31.0 \pm 7.09$ propagules $/ \mathrm{cm} 2$ on flank. 0 147 and $30.85 \pm 7.06$ propagules $/ \mathrm{cm} 2$ on shoulder, besides $0-166$ and $50.07 \pm 13.04$ propagules $/ \mathrm{cm}^{2}$ on neck surfaces after hose-spraying the whole each of their carcasses with tap water for one minute followed by wiping with sterilized cloth until removal most of visible dirts. On the other hand. apprectable reduction in mould propagules over the abdominal flap surfaces can also be obtalned, as their ranges and mean levels were $0-49$ and $28.08 \pm 3.07,0-70$ and 26.01 \pm 5.96 . together with $0-91$ and $23.0 \pm 4.99 / \mathrm{cm}^{2}$ after an independent spraying of each surveyed surface for one minute with $0.27 \%$ benzoic acid. $2 \%$ acetic acid, and $2.5 \%$ potassium sorbate solutions, consecutively. These findings emphasized that the considerable reduction levels in mould contamination were achieved after application of the first abattoir decontamination trial, with the greatest reduction was occurred on shoulder $(49.26 \%)$, followed by 45.72 .43 .57 . and $33.41 \%$ reductions on flank, round, and neck surfaces after hose-spraying the whole each of 
their carcasses with tap water for one minute. while the furthest mould decontamination was recognized by percentages of $67.35 .60 .87,68.88$, and $50.86 \%$ onto the same surfaces, successively after hose-spraying the whole each of their carcasses with tap water for one minute followed by wiping with sterlized cloth until removal most of visible dirts (second abattoir decontamination trail), in addition to the mould reductions resulted after using the three independent laboratory decontamination trlals onto the abdominal flap surfaces: $53.12 \%$ was the greatest decrease percentage in mould contamination induced by the one minute-spraying each tested surface with $2.5 \%$ potassium sorbate solution (third laboratory decontamination (rial) followed by $46.98 \%$ caused by the one minute-spraying every surveyed surface with $2 \%$ acetic acid solution (second laboratory decontamination trial) together with $42.76 \%$ elicited by the one minutespraying each investigated surface with $0.27 \%$ benzolc acld solution (first laboratory decontainination tral) (Table, 4).

With reference to the mould population detected onto the examined untreated carcass surlaces, the highest intensities were determined over both round and neck surfaces followed by those found on shoulder and flank ones. whereas the least mould contamination levels were observed on the abdominal flap surfaces. These findings corresponded, to large extent. with those obtalned by Abd-Allah (2005) onto the similar surfaces of beef carcasses. In comparison with the obtained mould intensities. Yassien et al. (1989) recovered approximately simflar mould populations onto the outside shoulder and thigh surfaces of surveyed cattle carcasses (mean values of 120 and 56 propagules/cm2, respectively), whereas the lower mould contamination levels on similar beef carcass surfaces (mean values of $31.15-83.5$ propagules $/ \mathrm{cm}^{2}$ ) were detected by Abd-Allah (2005), on the contrary, exceedingly higher mould intensitues by mean values of $2 \times 10^{2}-2 \times 10^{3}$ propagules $/ \mathrm{cm} 2$ determined by Eldaly et al. (1988), and by mean values of $98=$ 266 propagules $/ \mathrm{cm}^{2}$ estimated by Elgazzar (1992) over the cattle carcass surfaces. together with the mean values of mould contamination as $2.46 \times 103-2.82 \times 103$ propagules $/ \mathrm{cm}^{2}$ recognized by Shabanh (1995), and as $5.67 \times 104$ propagules $/ \mathrm{cm}^{2}$ evaluated by Hassan (2004) onto the sheep carcass surface.

Concerning the efficacy of first and second abattoir decontamination trials in ascending reduction of mould contamination levels on the surveyed carcass surfaces, the resulted reduction percentages ( $33.41-49.26 \%$ \& $50.86-68.88 \%$, consecutively) coordinated with Patterson (1968) who established that the spray-washing of carcass reduces the mould propagules onto its surface by removing the liquid film containing propagules before they become more closely attached with the rough outside (subcutaneous) surface of the dressed carcass. Additional removal of visible dirts, having some mould propagules, by the sterilized cloth onto the hose-sprayed carcass surface could enhance its microbial safety through reaching to the ultimate mould decon- 
tamination (Gill, 2004). Moderately higher reduction percentages in mould contamination over the beef carcass surfaces (38.68 - 60.48\% \& 60.38 - 77.84\%) obtained by Abd-Allah (2005) after treating them with identical two abattoir decontamination trials, respectively. However. lower decrease level (about 18\%) in mould population was detected by Sakhare et al. (1999) on the surface of dressed chicken carcasses after spraying them with tap water. In comparison with yeasts. the decontaminating effects of these abattoir trails against yeasts werc higher, in all cases, than that against moulds found on carcass surfaces, where their effectiveness against yeasts simulating. to large extent, that against bacterla (Mohammed, 2004).

With respect to the reducing effect of $0.27 \%$ benzoic acid on the intenslfies of mould contanination of carcass surfaces. the reduction percentage obtained in the present study $142.76 \%$ rcduction) correspond with Chistester and Tanner (1972), Luck (1986). Prasai et al. (1991), and Frazter and Westhoff (1995) who emphasized that the benzoic acid can inhiblt the nrould growth owing to its antimycotic effect. Furthermore, the Inhibltory concentrations of benzoic acid against moulds are recommended by Chipley (1993) as a range of $20.2000 \mathrm{mg} / \mathrm{ml}$. However. lower reduction percentage (about $11 \%$ In mould population was detected onto the outsicle surface of cattle carcasses by Nassar et al. (1995) after swabbing each of them with $0.7 \%$ benzoic acid solution for 3 - 5 minutes. Meanwhile, the bigher mould decontamination percentage (76.53\%) established on beef carcass surfaces as a result of identical $0.27 \%$ benzoic acid triał (Abd-Allah, 2005). As regards the decontaminating effect of $2 \%$ acetic acld solution on the mould population over the surveyed carcass surfaces, the decline percentage in mould containination determined in the present work (46.98\%) may be supported by the findings olstained by Awrad (1994) who could retard the appearance of visible mould growth onto the outside surfaces of luncheon sausage, hung at ordinary temperature simulating the market condition. for 4 days after spraying each of them with $1 \%$ acetic actd solution for one minute. Greater reduction percentages in mould contamination $(88.78$ and $66.80 \%)$ over the broiler carcass surfaces. after in. dependent spraying each of them with $0.5 \%$ and $2 \%$ acetic acld solutions, determined by Sak. hare et al. (1999) and Eldaly et al. (2002). respectively, as well as onto the beef carcass surfaces (58.01\%)after treating each of them with acetlc acid trial identical to that of the present study (Abd-Allah, 2005). Inspection of the selective fungal decontaminating effect of the $2 \%$ acetic acid trial onto the examined carcass surfaces, reveal that the acetic acid was more effective against yeasts than moulds; this findings agreed with that reported by Banwart (1989), Frazier and Westhoff (1995), and Farkas (2001). Concerning the decreasing effect of $2.5 \%$ potassium sorbate trial on the intensities of surface mould contamination applied in the present work. the obtained decreasing percentage (53.12\%) can be emphasized through the finding of Awad (1994) who delayed the visible mould growth over the outside surfaces of luncheon sausage. hung at 
the ordinary room temperature slmulating the market condition, for 24 days after spraying each of them with $5 \%$ sorbic acid solution for one minute: together with the finding of Baldock et al. (1979) who prevented the mould growth onto cured ham surfaces for 60 days after their sprayIng with 5 or $10 \%$ potassium sorbate solution; in addition to the result of Sofos and Busta (1981) who established that the dipping of dry sausage casings in $2.5 \%$ potassium sorbate solution could prevent the mould growth over the product surface during drying pertod. An extremely higher decline percentage (95.04\%) in mould population was obtalned by Hassan (2004) onto the sheep carcass surfaces after their spraying with $0.2 \%$ potassium sorbate solution, while lower reduction level in mould contamination (45.68\%) was detected by Abd-Allah (2005) onto the cattle carcass surfaces after their treatment with a potassium sorbate trial identical to that applied in the present study. Sensory evaluation of the laboratory-treated flaps exhibited no bleaching, discoloration. abnormal odor. or abnormal taste was detected in their meat after spraying each of them with any of $0.27 \%$ benzoic acid. $2 \%$ acetic acid, and $2.5 \%$ potassium sorbate solutions for one minute. because these organic acids and their salts were used in the present study by approved low concentrations.

Collectively, all fungal decontamination trials (abattoir and laboratory ones) applied in this work could reduce the yeast contamination by higher levels than that of mould type onto all the surveyed carcass surfaces. In conclusion, the abattoir (mechanical) decontamination trials are considered the most effectlve and applicable methods for reducing fungal decontamination on the freshly dressed carcasses at municipal (old-fashioned) abattoirs, whereas the laboratory (chemical) decontamination trals can be done in meat factories.

Results in Table (5) reveal that a total of Identified 619 (100\%) mould strains belonged to 20 genera could be isolated from all surveyed surfaces before and after decontamination trials. distributed as 109 (17.61\%) Penicillium. 104 (16.80\%) Aspergillus. 74 (11.95\%) Cladosporium. 53 (8.56\%) Alternarla, and 51 (8.24\%) Monilielta strains at the top, followed by 26 (4.2\%) Humicola. $24(3.88 \%)$ Geotrichum candidum. $23(3.72 \%)$ Fusarlum, 22 (3.55\%) Absidia. 20 (3.23\%) Syncephalastrum, and 19 (3.07\%) Acremonium strictum stralns, together with 16 (2.58\%) Stemphylium. 13 (2.1\%) Mucor, 12 (1.94\%) each of Aureobasidium and Paecilomyces, alongside 9 (1.45\%) every of Scopulariopsis and Trichoderma, $8(1.29 \%)$ each of Rhizopus and Botrytis. besides 7 (1.13\%) Thamnidium strains. The recovered 104 (100\%) Aspergillus strains were further characterized into 11 groups and distributcd as $42(40.38 \%) \mathrm{A}$. niger, and $23(22.12 \%) \mathrm{A}$. flavus strains at the top. followed by $9(8.65 \%)$ A. fumigatus, $7(6.73 \%)$ each of A. amstelodami and $\Lambda$. candldus. $5(4.81 \%)$ every of A. sydowil and A. ochraceus, in addition to $2(1.92 \%)$ each of A. clavatus and A. nidulans, alongside $1(0.96 \%)$ every of A. chevalier and A. wentii (Table. 6). Nearly similar percentages of Penicillum (17.94\%), Aspergillus (18.72\%). Cladosporlum (11.9\& 12.21\%). Alter- 
naria $(8.7 \& 8.94 \%)$, Geotrichum candidum ( $3.3 \& 3.63 \%)$. Fusarium ( $3.35 \& 3.8 \& 4.01 \%)$. Absidia (3.94\%). Mucor (2.1\%). Aureobasidium (1.5\%). Paecilomyces (2.2\%). Scopulariopsis (1.4\%). Trichoderma (1\%), Rhizopus (1.4\%), Botrytis ( $1.3 \& 1.5 \%$ ), and Thamniclium strains (1.6\%) dctected onto the surface of cattle and sheep carcasses as well as of fresh meats (Refai and Loot, 1969: Mansour, 1986; Eldaly et al., 1988; Yassien et al., 1989; Elgazzar, 1992: and AbdAllah, 2005). whereas higher levels of Penicillium (21.5\&26.11\&28.49\%). Aspergillus (28.7\& 34.6 \& 39.66\%). Cladosporium (25.5\%). Alternarla (10.34\%). Moniliella (13.17\%). Hunicola (12.21\%). Geotrichum candidum (14.31\%), Absidia $6.8 \%$ ). Syncephalastrum (5.5\%). Acremonium strictum (4.58\%). Stemphylium (5.3\%), Mucor (4.5 \& 8.1\%). Aureobasidium (2.5\%). Paecilomyces (2.8\%). Scopulartopsıs $(2.2 \%\}$. Trichoderma (3.94\%), Rhizopus $\{1.6 \& 3.94 \& 5.2 \%$ ). Botrytis $(2.7 \%)$, and Thamnidium strains $(3.4 \%)$ isolated from the surface of cattle and shcep carcasses alongside of fresh meats plus frozen beef and poultry (Refai and Loot, 1969: Mansour, 1986; Eldaly et al., 1988; Yassien et al., 1989; Mansour et al., 1990; Elgazzar, 1992; and Abd-Allah, 2005), on the contrary. lower percentages of Penictlifum (12.1\%). Aspergillus (13.93\%). Cladosportum (5 \& 6.42\%). Alternaria $(0.95 \& 2.1 \& 3.3 \%$ ). Geotrichun candidum $(0.49 \& 1.2 \%)$. Fusarium $(1.7 \& 2.46 \%)$. Acremonium strictum $10.5 \& 2.4 \%)$. Stemphylium (0.19\%). Mucor (0.38 \& 0.98\%), Aureobasidium (0.38\%). Scopularlopsis (1.15\%). Trichoderma $(0.5 \%)$, and Thamnidium strains $(0.1 \%)$ deternined over the surface of cattle and sheep carcasses together with fresh meats (Refai and Loot, 1969; Mansour, 1986; Eldaly et al., 1988; Yassien et al., 1989; Elgazzar, 1992; and Abd-Allah, 2005). On the other hand, approximately analogous percentages of A. niger $(42.2 \%)$. A. Slavus (19.18\%). A. candiclus (7.1\%), $\wedge$. niclulans $(2.47 \%)$, and A. chevalierl strains (1.37\%) estimated onto cattle carcass surfaces (Elgazzar, 1992 and Abd-Allah, 2005). however, higher levels of A. niger (49.32\%). A. Tumigatus (11.7\%). A. amstelodami (13.7\%). A. candidus (14.7\%), A. sydowil (12.2\%). A. clavatus $(16.7 \%)$. A. cheralieri (3.4\%), and A. wentii strains (2.4\%) isolated from the surface of catle carcasses as well as of frozen beef and poultry (Abdel-Rahman et al., 1985; Elgazzar, 1992; and Abd-Allah, 2005). while. lower percentages of A. Mavus (5.63 \& $17.6 \%), \Lambda$. fumigatus $(1.37 \%), \Lambda$. amsteloclami $(4.5 \%)$. A. candidus $(2.47 \%)$, and A. ochraceus strains $(3.9 \& 4.11 \%)$ detected over calle carcass surfaces (Eldaly et al., 1988; Elgazzar, 1992; and Abd-Allah, 2005). 
Elgazzar M. M. M.

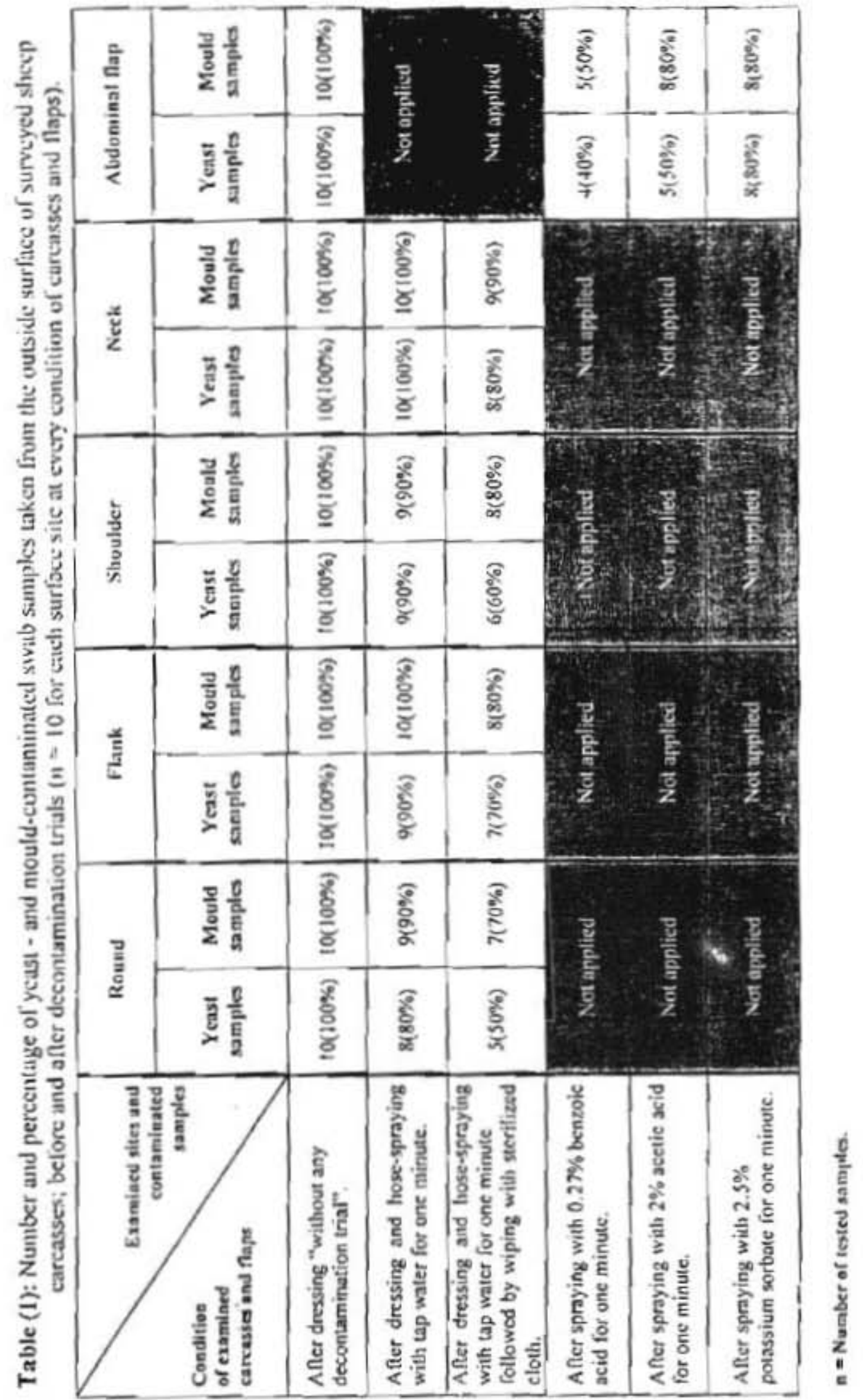

Mansoura, Vet. Med. J.

Vol, VII, No, 1, 2005 


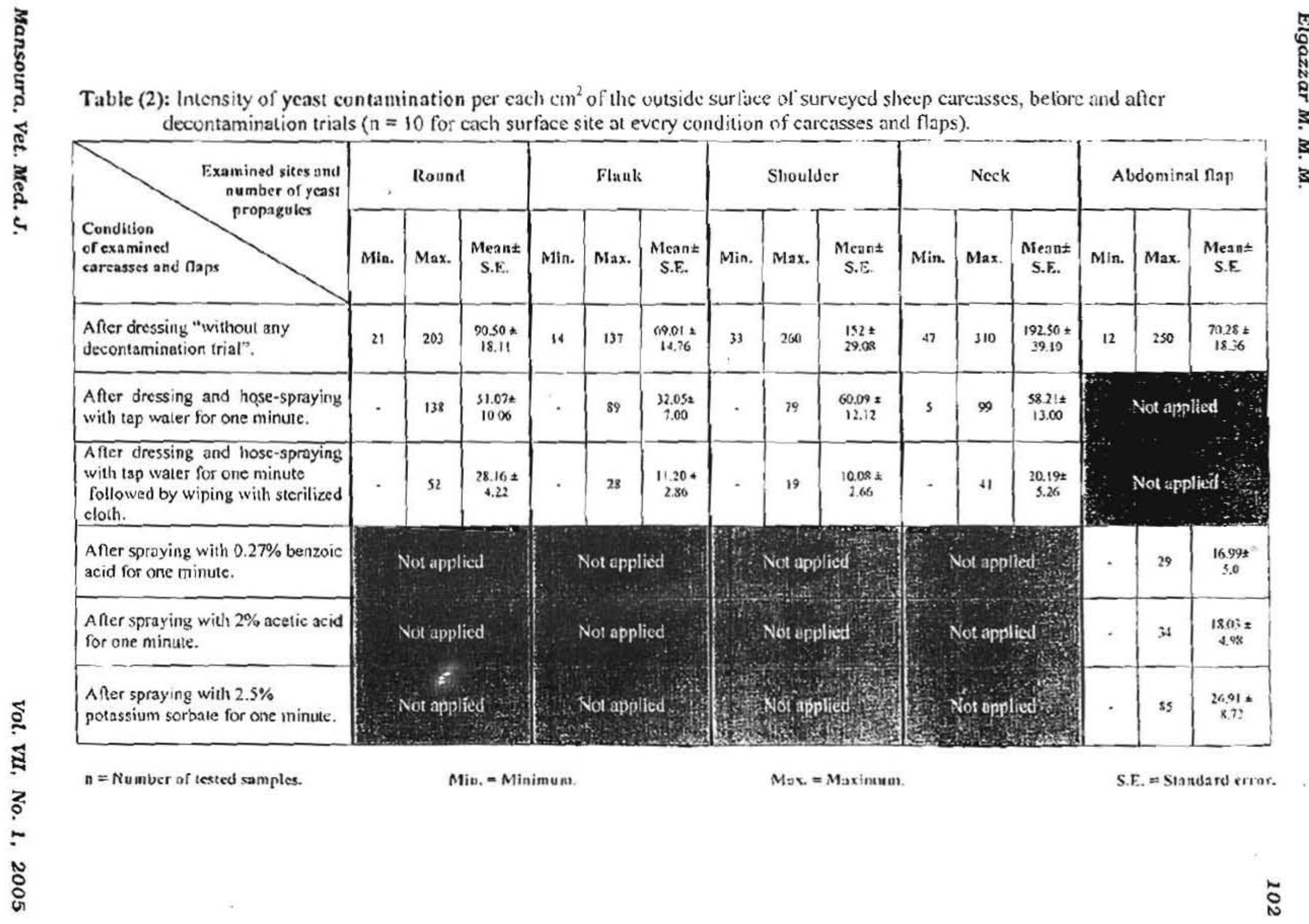


Table (3): Intensity of mould contamination per each $\mathrm{cm}^{2}$ of tae outside surlace of surveyed shecep circiasses, belore and afler decontamination trials ( $n=10$ for each surface site at every condition of carcasses and flaps).

\begin{tabular}{|c|c|c|c|c|c|c|c|c|c|c|c|c|c|c|c|}
\hline \multirow{2}{*}{$\begin{array}{l}\text { Condition } \\
\text { of examined } \\
\text { carcasses and flaps }\end{array}$} & \multicolumn{3}{|c|}{ Round } & \multicolumn{3}{|c|}{ Flank } & \multicolumn{3}{|c|}{ Shoulder } & \multicolumn{3}{|c|}{ Neck } & \multicolumn{3}{|c|}{ Abdominal flap } \\
\hline & Min. & Max. & $\begin{array}{l}\text { Mean } \pm \\
\text { S.E. }\end{array}$ & Min. & Max. & $\begin{array}{l}\text { Mean } \pm \\
\text { S.E. }\end{array}$ & Mln. & Max. & $\begin{array}{l}\text { Meant } \\
\text { S.E. }\end{array}$ & Min. & Max. & $\begin{array}{l}\text { Meant } \\
\text { S.E. }\end{array}$ & Min. & Max. & $\begin{array}{l}\text { Meant } \\
\text { S.E. }\end{array}$ \\
\hline $\begin{array}{l}\text { After dressing "without any } \\
\text { decontamination trial". }\end{array}$ & 17 & 204 & $\begin{array}{l}116 \pm \\
21.93\end{array}$ & 15 & 181 & $\begin{array}{c}79.23 * \\
19.07\end{array}$ & 20 & 316 & $\begin{array}{c}94.50 \neq \\
21.89\end{array}$ & 33 & 349 & $\begin{array}{l}1111.9 \pm \\
22.31\end{array}$ & 14 & 127 & $\begin{array}{c}49.06 \pm \\
12.08\end{array}$ \\
\hline $\begin{array}{l}\text { Affer dressing and hose-spraying } \\
\text { with tap water for one minutc. }\end{array}$ & - & 90 & $\begin{array}{l}44.05 \pm \\
9.16\end{array}$ & 19 & 107 & $\begin{array}{l}43.01 k \\
9.96\end{array}$ & $i^{\circ}$ & 198 & $\begin{array}{l}47.95:= \\
11.01\end{array}$ & 24 & 210 & $\begin{array}{c}67.80 . * \\
16.05\end{array}$ & & $\mathrm{Not}$ ajp & ied \\
\hline $\begin{array}{l}\text { After dressing and hose-spraying } \\
\text { with tap water for one minute } \\
\text { followed by wiping with sterilized } \\
\text { cloth. }\end{array}$ & - & 63 & $\begin{array}{c}27.10 \pm \\
6.98\end{array}$ & i & 83 & $\begin{array}{c}31.00 \pm \\
7.09\end{array}$ & T & 147 & $\begin{array}{c}30.85 \neq \\
7.06\end{array}$ & & 160 & $\begin{array}{l}30,07 * \\
13.04\end{array}$ & & Not app & ied: \\
\hline $\begin{array}{l}\text { After spraying with } 0.27 \% \text { benzoic } \\
\text { acid for one minute. }\end{array}$ & & Not ap: & & & Not app & & & & & & 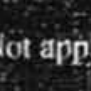 & & - & 49 & $\begin{array}{c}28.08 \pm \\
3.07\end{array}$ \\
\hline $\begin{array}{l}\text { Afler spraying with } 2 \% \text { acetic acid } \\
\text { for one minutc. }\end{array}$ & & fot app & & & Notap & & & Not & & & bo. & & • & 20 & $\begin{array}{l}26.01 \neq \\
\$ .96\end{array}$ \\
\hline $\begin{array}{l}\text { After spraying with } 2.5 \% \\
\text { potassium sorbate for onc minute. }\end{array}$ & & a & & & $\mathrm{ot}$ & & & & & & 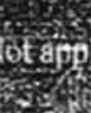 & & - & 91 & $\begin{array}{c}23.900 \neq \\
4.99\end{array}$ \\
\hline
\end{tabular}


Table (4): Reúuction percentages* of yeast and mould contamination on the outside surface of surveyed sheep carcasses after decontanination trials $(n=10$ tor each surface sitc at every condition of carcasses and llans).

\begin{tabular}{|c|c|c|c|c|c|c|c|c|c|c|}
\hline & \multicolumn{2}{|c|}{ Round } & \multicolumn{2}{|c|}{ Flank } & \multicolumn{2}{|c|}{ Shoulder } & \multicolumn{2}{|c|}{ Neck } & \multicolumn{2}{|c|}{ Abdominal nap } \\
\hline $\begin{array}{l}\text { decontamination } \\
\text { trials }\end{array}$ & Yensts & Moulds & Ycists & Moufds & Ycusts & Moulds & Yeasts & Moulds & Yeasts & Moulds \\
\hline $\begin{array}{l}\text { Hose-spraying with tap water } \\
\text { for one minule. }\end{array}$ & $55.72 \%$ & $43.57 \%$ & $53.56 \%$ & $45.72 \%$ & $60.47 \%$ & $49.26 \%$ & $69.76 \%$ & $33.41 \%$ & \multirow{2}{*}{\multicolumn{2}{|c|}{$\begin{array}{l}\text { Nut applied } \\
\text { Not applied }\end{array}$}} \\
\hline $\begin{array}{l}\text { Hose-spraying with lap water } \\
\text { for one minutc followed by } \\
\text { wiping with stcrilized clolls. }\end{array}$ & $85.46 \%$ & $68.88 \%$ & $83.77 \%$ & $60.87 \%$ & $93.37 \%$ & $67.35 \%$ & $89.51 \%$ & $50.86 \%$ & & \\
\hline $\begin{array}{l}\text { Spraying with } 0.27 \% \text { benzoic } \\
\text { acid for one minute. }\end{array}$ & \multicolumn{2}{|c|}{ Not applied } & \multicolumn{2}{|r|}{ pplied } & \multicolumn{2}{|c|}{ Worapplied } & \multicolumn{2}{|c|}{ Not applied } & $75.83 \%$ & $42.76 \%$ \\
\hline $\begin{array}{l}\text { Spraying with } 2 \% \text { acetic acid } \\
\text { for onc minute. }\end{array}$ & \multirow{2}{*}{\multicolumn{2}{|c|}{$\begin{array}{l}\text { Not applied } \\
\text { Notapylied }\end{array}$}} & \multirow{2}{*}{\multicolumn{2}{|c|}{$\begin{array}{l}\text { Not applied } \\
\text { Not applied }\end{array}$}} & \multirow{2}{*}{\multicolumn{2}{|c|}{ Yut splitid }} & \multirow{2}{*}{\multicolumn{2}{|c|}{$\begin{array}{l}\text { Not applied } \\
\text { Nofapplied } \\
\text { and }\end{array}$}} & $74.35 \%$ & $46.98 \%$ \\
\hline $\begin{array}{l}\text { Spraying with } 2.5 \% \text { potassium } \\
\text { sorbate for one minutc. }\end{array}$ & & & & & & & & & $61.71 \%$ & $53.12 \%$ \\
\hline
\end{tabular}

* Reduction percentage equal to the \% of mean value of the contantination intensity that lost affer decontansination trial. 
Table(5): Type, number, and percentage of mould strains isolated from the outside surface of round. flank, shoulder, neck. and abdominal flap of surveyed sheep carcasses. before and after decontamination trials.

\begin{tabular}{|c|c|}
\hline Mould genern & $\begin{array}{l}\text { No. and } \% \\
\text { of mould } \\
\text { strains }\end{array}$ \\
\hline $\begin{array}{l}\text { Penicillium } \\
\text { Aspergillus } \\
\text { Cladosporium } \\
\text { Alternaria } \\
\text { Moniliella } \\
\text { Humicola } \\
\text { Geotrichum candidum } \\
\text { Fusarium } \\
\text { Absidia } \\
\text { Syncephalastrum } \\
\text {.4cremonimm strictum } \\
\text { Stemphylium } \\
\text { Mucor } \\
\text {.Aureobasidium } \\
\text { Paecilomyces } \\
\text { Scopulariopsis } \\
\text { Trichoderma } \\
\text { Rhizopus } \\
\text { Bolrytis } \\
\text { Thamnidium }\end{array}$ & $\begin{array}{l}109(17.61 \%) \\
104(16.80 \%) \\
74(11.95 \%) \\
53(08.56 \%) \\
51(08.24 \%) \\
26(04.20 \%) \\
24(03.88 \%) \\
23(03.72 \%) \\
22(03.55 \%) \\
20(03.23 \%) \\
19(03.07 \%) \\
16(02.58 \%) \\
13(02.10 \%) \\
12(01.94 \%) \\
12(01.94 \%) \\
9(01.45 \%) \\
9(01.45 \%) \\
8(01.29 \%) \\
8(01.29 \%) \\
7(01.13 \%)\end{array}$ \\
\hline Total & $619(100 \%)$ \\
\hline
\end{tabular}

Table(6): Type, number, and percentage of aspergilli isolated from the outside surface of round, flank, shoulder. neck, and abdominal flap of surveyed slieep carcasses. before and after decontamination trials.

\begin{tabular}{|c|c|}
\hline $\begin{array}{c}\text { Aspergillus } \\
\text { groups }\end{array}$ & $\begin{array}{l}\text { No. and } \% \text { of } \\
\text { aspergilli }\end{array}$ \\
\hline $\begin{array}{l}\text { A. niger } \\
\text { A. flavins } \\
\text { A. funigatus } \\
\text { A. amstelodami } \\
\text { A. candidus } \\
\text { A. sydowii } \\
\text { A. ochracens } \\
\text { A. clavarns } \\
\text { A. nidulans } \\
\text { A. cheralieri } \\
\text { A. wentii }\end{array}$ & $\begin{array}{l}+2\left(40.38^{\circ} 0\right) \\
23\left(22.12^{\circ} 0\right) \\
9\left(08.65^{\circ} 0\right) \\
7\left(06.73^{\circ} 0\right) \\
7\left(06.73^{\circ} 0\right) \\
5\left(0+.51^{\circ} 0\right) \\
5\left(04.81^{\circ} 0\right) \\
2\left(01.92^{\circ} 0\right) \\
2\left(01.92^{\circ} 0\right) \\
1\left(00.96^{\circ} 0\right) \\
1\left(00.96^{\circ} \circ\right)\end{array}$ \\
\hline Total & $104(100 \%)$ \\
\hline
\end{tabular}




\section{REFERENCES}

Abd-Allah S. M. A. (2005) : Fungal contamination on bovine carcasses with trials for decontamInation. Master Thests of Vet. Med. Sc. (Meat Hygiene). Fac. Vet. Medicine. Mansoura University.

Abdel-Rahman H. A., Darwish A. and Hamdy M. (1985) : Mould affections of a meat cold store. Assiut Vet. Med. J. 14 (27): 131-134.

Arz J. A. (1967) : Pilzkunde. Von J. Cramer Lethre. In der A. R. Ganter Verlag Kommandit. Cesellschaft. Fl. 9490 Vaduz.

Awad H. A. (1994) : Mould free period in tradirional sausages as influenced by organic acids treatment. Benl-Suef Vet. Med. Res. IV (2): 442 - 455.

Ayres J. C., Mundt J. O. and Sandine W. E. (1980) : Microbtology of Foods. W. H. Freeman and Company. San Francisco.

Balrd-Parker A. C. (1980) : Organic acids. In: Microbial Ecology of Foods (Vol. I). Silliker J. H., Elliott R. P., Baird-Parker A. C., Bryan S. L., Christian J. H. B., Clarke D. S., Olson Jr. J. C. and Roberts T. A. (Eds.). pp. 126-135. International Commission on Microbiological Speciffcations for foods Academic Press. New York.

Baldock J. D., Frank P. R., Graham P. P. and Ivey F. J. (1979) : Potasslum sorbate as a fungistatic agent in country ham processing. J. Food Prot. 42: $780-783$.

Banwart G. J. (1989) : Basic Food Microbiology. 2nd Ed. An avi Book. Van Nostrand Relnhold. New York.

Barnett H. L. and Hunter B. B. (1972) : Illustrated Genera of Imperfect Fungi. 2nd Ed. Burgess Pub. Co.

Batista A. C., De Vasconcelos C. T., Fischmann O. and Staib F. (1961) : Fungos levedurifor mes efilamentosos de bovinos no recife. Publ. Inst. Microb. Unlver. Reclfe. (Brasil).

Bullerman L. B. (1985) : Effects of potasslum sorbate on growth and ochratoxin production by Aspergillus ochraceus and Penicillium species. J. Food Prot. 48: $162-165$.

Bullerman L. B., Hartman P. A. and Ayres J. C. (1969a) : Aflatoxin production in meats I. Stored meats. Appl. Microbiol. 18 (5): $714-717$.

Bullerman L. B., Hartman P. A. and Ayres J. C. (1969b) : Aflatoxin production in meats 11. Aged dry salamis and aged country-cured hams. Appl. Microbiol. 18 (5): $718-722$.

Chao H. J., Schwartz J., Muton D. K. and Burge H. A. (2002) : Populations and determinants 
of air borne fungt in large office buildings. Env. Health Prospectives 110: 777 - 782 .

Chipley J. R. (1993) : Sodium benzoate and benzoic acid. In: Antimicrobials in Foods, 2nd Ed., Davidson P. M. and Branen A. L. (Eds.). Marcel Dekker, Inc.. New York. N. Y., pp. 11 48.

Chistestex D. F, and Tanner F. W. (1972) : Antlmicrobtal food additives. In: Handbook of Food Additives. Eurta T. (Ed.), pp. 115. Chem. Rubber Pub. Co. Clevelan. Ohio.

Chrtstensen M., Raper K. B. and States J. S. (1978) : Two new Aspergillus nidulans group members from Wyoming solls. Mycologia 70: 332 - 3442 .

Dickson J. S. and Anderson M. E. (1992) : Microblological decontamination of food antmal carcasses by washing and sanitizing systems: A review. J. Food Prot. 55 (2): 133 - 140.

Eldaly E., Abdel-Galil Y. and Saleh E. (1988) : Studies on food--borne fungl on carcass surface and alr in Zagazig abattoir. The Bulletin of the High Institute of Public Health 18 (5): $1065-1071$.

Eldaly E. A., Morshdy A. M. and Sallam K. I. (2002) : Improving the sanitary status of broiler carcasses during their processing. 6 th Vet. Med. Zag. Conference.

Elgazzar M. M. M. (1992) : Prevalence of mould on the cattle carcasses slaughtered at Zagazlg abattoir. M. V. Sc. Thesis, Fac. Vet. Med., Zagazig Univ., Egypt.

Empey W. A. and Scott W. J. (1939) : Investigations on chilled beef. 1. Microbial contamination acquired in the meatworks. Councll Scl. Ind. Res. [Aust.] Bull. 126.

Farghaly R. M. M. (1985) : Incidence of moulds in the intestinal tract of slaughtered animals in Upper Egypt in relation to meat hyglene with spectal reference to genus Aspergillus. $M$. V. Sc. Thesis, Fac. Vet. Med., Asslut Univ., Egypt.

Farkas J. (2001) : Physical methods of food preservation. In: Food Microbiology: Fundamentals and Frontlers. 2nd Ed., Doyle M. . Beuchat L. and Montiville T. (Eds.). ASM Press. Washington. D. C.

Frazier W. C. and Westhoff D. C. (1995): Food Microbiology, 4th Ed. Tata McGraw-Hill PubIIshing Company Limited. New Delhi.

Gill C. O. (2004): Visible contamination on animals and carcasses and the microbiological condition of meat. J. Food Prot. 67 (2): $413-419$.

Gracey J. F. and Collins D. S. (1992) : Meat Hygiene, 9th Ed. Bailli rc Tindall.

Groer G. G. (1982) : Mechanism of beef shelf llfe extension by sorbate. J. Food Prot. 45: 82 - 83. 
Elgazzar M. M. M.

Hamdy M., Yassien N. A., and Mansour N. K. (1991): Mycological investigations of air in camel and cattle slaughter halls. Flelschwirtschaft 1: $55-56$.

Hassan M. A. (2004): Control of mycological hazard in sheep carcasses with speclal reference to aflatoxins. SCVMJ VII (2): 359 - 366.

Hill R. A., Wilson D. M., Burg W. R. and Shotwell O. L. (1984): Vlable fungt in corn dust. Appl. Environ. Microbiol. 47: 84 - 87.

Ismall M. A., Abou Elala A. H., Nassar A., and Michail D. G. (1995) : Fungal contamination of beef carcasses and environment in a slaughterhouse. Food Microbiol. 12: $441-445$.

Jay J. M. (1992): Modern Food Microblology. $2^{\text {th }}$ Ed. Chapman-Hall, New York.

King A. D., Hocking A. D. and Pitt J. I. (1979) : Dichloran-rose bengal medium for enumeration and isolation of molds from foods. Appl. Environ. Microbiol. 37: 959 - 964.

Klare H. J. (1970) : Intestinal contents of slaughtered animal as an important sourcc of mould contamination of meat and meat products. Flelschwirtschaft 50 (11): $1507-1510$.

Kotula A. W., Lusbu W. R., Crouse J. D. and de Vries B. (1974) : Beef carcass washing to reduce bacterial contamination. J. Animal Scl. 39:674 - 679 .

Lacey J. (1973) : Actinomycetes and fungus spores In farm air. J. Agr. Labour. Sci. I: 61- 78.

Luck B. (1986): Chemische Lebensmittel Konserveirung. Stoffe, Wirkungen. Methoden. SprigerVerlag, Berlin, Germany.

Luek F. (1980): Antimicrobial Food Additives, pp. 265. Springer Verlag. Berlin.

Mansour N. K. (1986): Zum Vorkommen Von Schimmelpilzen der Gattung Cladosporium link Ex Fries auf Schaffletsch. Ph. D. Thesis, M nchen, Germany.

Mansour N. K., Hamdy M., Yassien N. A., and Refal M. (1990) : Dematiaceous hyphomycetes in slaughtered camels, cattle and surroundings at Calro abattoir. Assiut Vet. Med. J. 24: 145 .

McKenzie F, and Taylor G. S. (1983) : Fusartum populations in British solls relative to different cropping practice. Trans. Brit. Mycol. Soc. 80: 409 - 413.

Mohammed M. A. M. (2004) : Sanitary evaluation and reduction trials for surface microbial contamination of sheep carcasses at Mansoura abattoir. M. V. Sc. Thesis. Fac. Vet. Med., Mansoura Univ., Egypt.

Mulder R. W. (1985) : Decreased mlcrobial contamination during poultry processing. March $52 \cdot 55$ 
Elgazzar M. M. M.

Nakae T., Kataoka K. and Xoneya T. (1976) : Fungal distribution in milk and the milking environment. Japanese J. Zootechnical Sci. 47 (7): 402 - 410.

Nassar A., Ismail M. A. and Abou Elala A. (1995) : The role of benzoic acid as a fungal decontaminant of beef carcasses. Fleischwirtschaft 75 (10): $1218-1220$.

Notermans S. H. W., Texbljhe R. J. and Schothorst M. (1980) : Removal of fecal contamination of broilers by spray cleaning during evisceration. British Poultry Sci. 21: $115-121$.

Patterson J. T. (1968) : Hyglene in meat orocessing plants III. Methods of reducing carcass contamination. Record of Agricultural Research Min. Agiric. Northern Ireland 17 (1): $7-12$.

Patterson J. T. (1971) : Microblological assessment of surfaces. J. Food Technol. 6: 63 - 72.

Pitt J. I. and Hocking A. D. (1985) : Fungi and Food Spoilage. Academic Press, Sydney. Orlando. San Diego, New York, London, Toronto, Montreal, and Tokyo.

Prasai R. K., Acuff G. R., Lucla L. M., Hale D. S., Savell J. W. and Morgan J. B. (1991): Microbiological effects of acid decontamination of beef carcasses at various locations in processing. J. Food Prot. 54, 868-872.

Ramirez C. (1982) : Manual and Atlas of the Penicillia. El-Seuier Blomedical Press. Amsterdam. New York, Oxford.

Raper K. B. and Fennell D. I. (1965) : The genus Aspergillus. Williams and WilkIns Co., Baltimore, England.

Raper K. B. and Thom C. (1949) : A Manual of the Penicillta. Williams and Wilkins Co., Baltimore, England.

Refal M. and Loot A. (1969) : Studies of mould contaminations of meat in slaughterhouses. butcher's shops and in cold stores. Mykosen 12 (10): $621-624$.

Rosenzwelg W. D., Minnigh H. and Pipes W. O. (1986) : Fungi in potable water distribution systems. J. American Water Works Association 78 (1).

Sakhare P. Z., Sachtndra N. M.,Yashoda K. P. and Narasimha Rao D. (1999): Efficacy of Intermittent decontamination treatments during processing in reducing the microblal load on broller chicken carcass. Food Control 10: 189 - 194.

Samson R. A. (1979) : A completion of the aspergilli described since 1965. Studies in Mycology No. 18.

Samson R. A., Hoekstra E. S. and van Oorschot C. A. N. (1981) : Introduction to Food-borne Fungi. 1st Ed. Centraalbureau voor Schimmelcultures. Baarn. The Netherland. 
Samson R. A., Stolk A. and Hadlock R. (1976) : Revision on the subsection lasciculate of Peniclllium and some allied species. Studies in Mycology No. 11.

Schtpper M. A. A. (1978) : 1. On certain specles of Mucor with key to all accepted species. 2. On the genera Rhizopus and Parasitella. Centraalbureau voor schimmelcultures. Baarn. Institute of the royal Netherlands Academy of Sciences and Letters. Study in Mycology No. 17.

Shabanh E. S. E. (1995) : Mycological aspects of sheep carcase surfaces. M. V. Sc. Thesis. Fac. Vet. Med., Zagazig Univ., Egypt.

Stragusa G. R. (1995) : The effectiveness of carcass decontamtnation systems for controlling the presence of pathogens on the surfaces of meat animal carcasses. J. Food Safety 15. 229 $-238$.

Snedecor G. W. (1971) : Statistical Methods. 14th Ed. Ames.. lowa. The lowa State Universily Press.

Sofos J. N. (1989) : Sorbates: Food Preservitives. CRC Press, Boca Raton, Fl.

Sofos J. N. and Busta F. F. (1981) : Antimicrobial activity of sorbate. J. Food Prot. 44 (8): 614 622.

Thornton H. and Gracey J. F. (1974) : Textbook of Meat Hygiene. 6th Ed. The English Language Book Soclety and Balltere Tindall.

Weiser H. H. (1962) : Practícal Food Microblology and Technology. Avi Publishing Company, Inc., Westport, Connecticut.

Yassien N., Mansour N. K., Eldaly E. and Darwish A. (1989) : Contamination of slaughtered camels, cattle and their surroundings with moulds in urban ab ttolr. Alex. J. Vet. Sct. 5 (2): 185 .

Zycha H. R., Slepman H. R. and Linnemann G. (1969) : Mucorales Elne Beschrlebung aller Guttungen und Artern dieser Pilzegrupp. D. 3301 Lehre, J. Cramer. 
الملخص العربى

محسـاولات لإزالــة التلـوث الفطــى على ذباتــح الغنــم

\author{
محمد محمد محمد إبرأهيم الجـــزار \\ تسم الرتابة المصبة على الأغذين - كلية الطب البيطرى - بامعة المنصورن
}

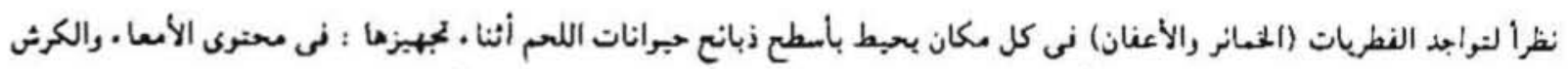

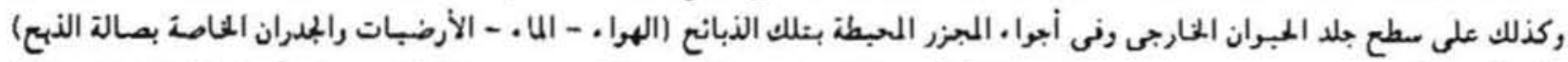

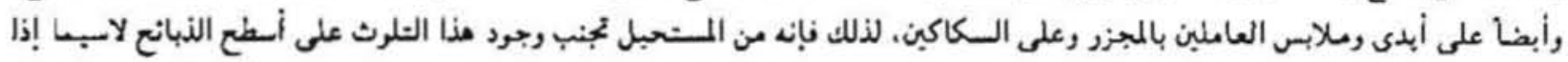

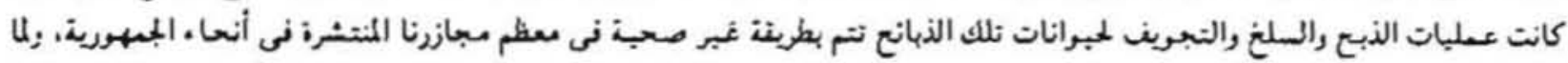

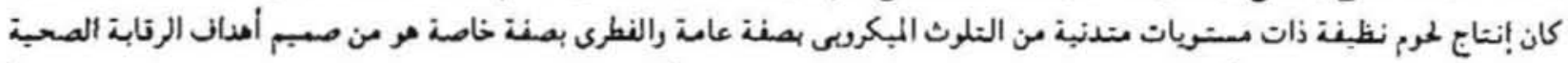

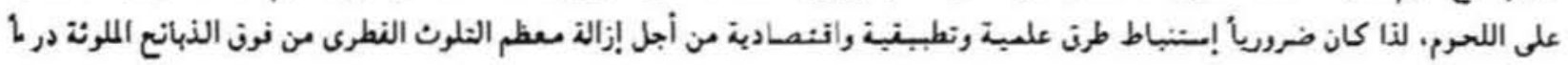

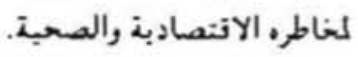

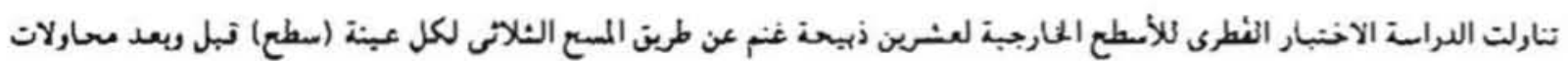

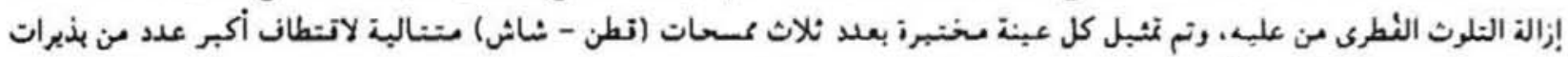

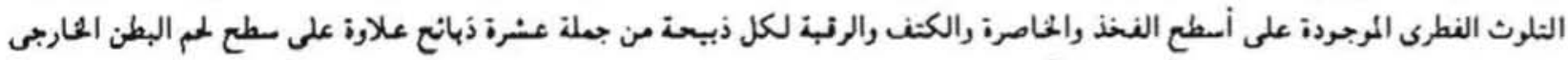

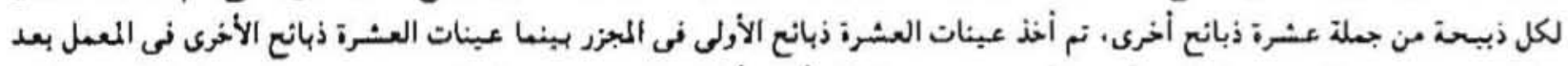

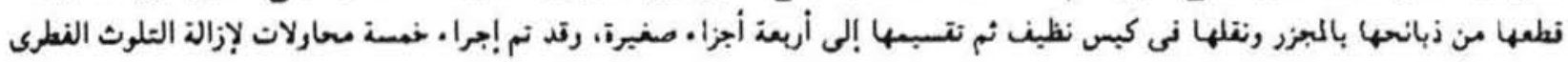

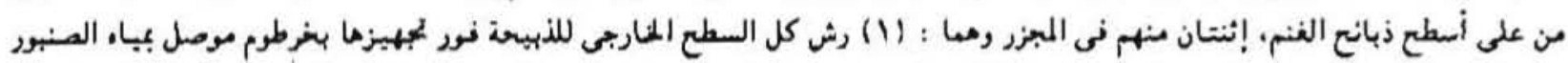

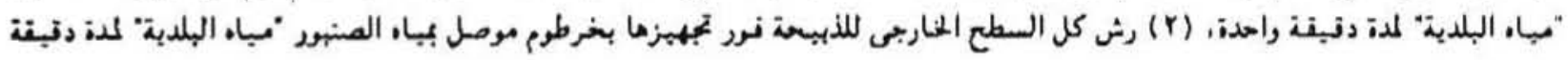

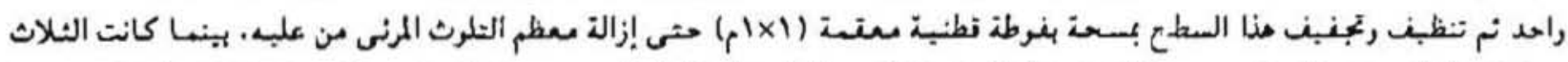

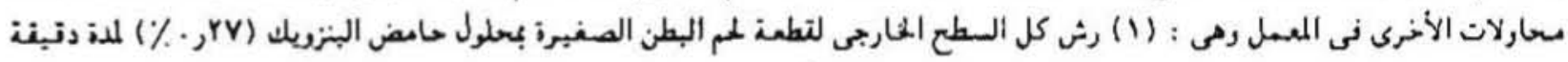

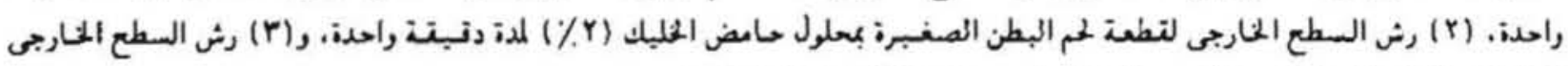

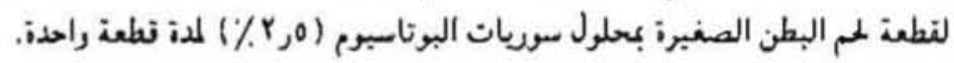

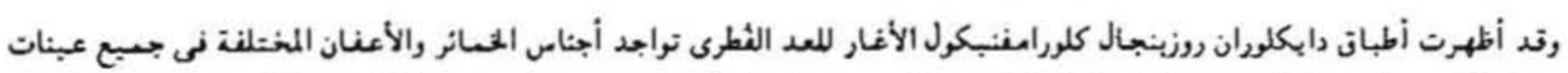

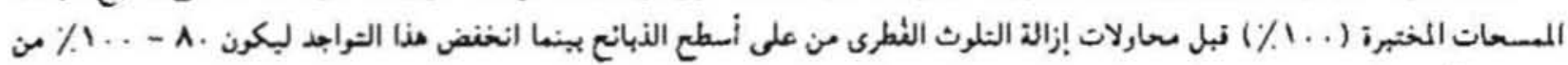

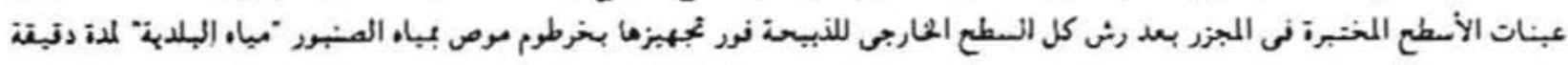

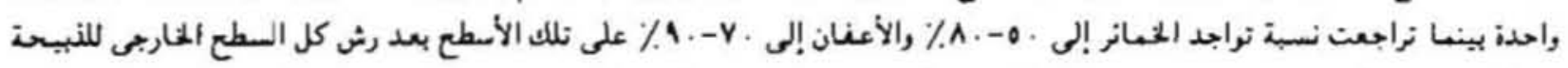

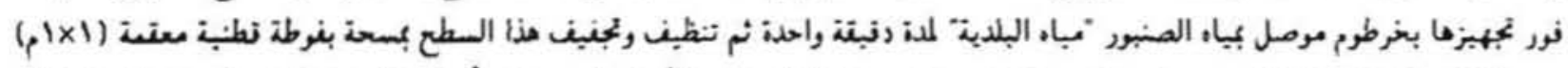

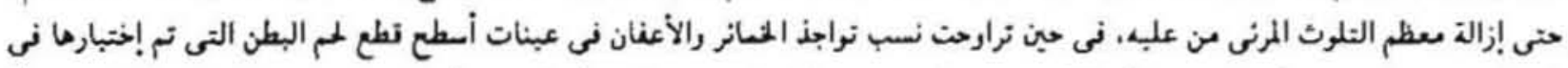

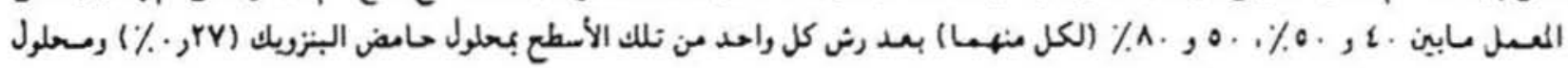




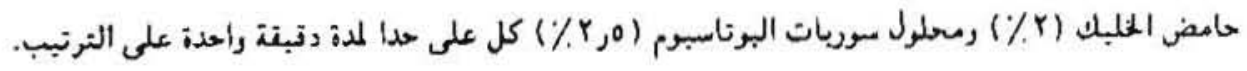

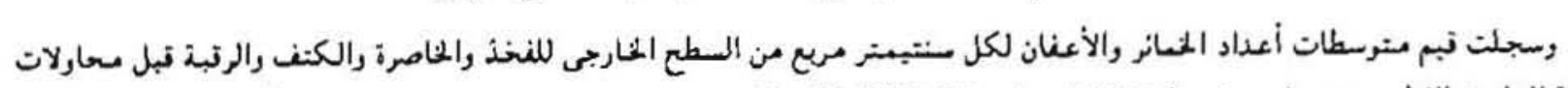

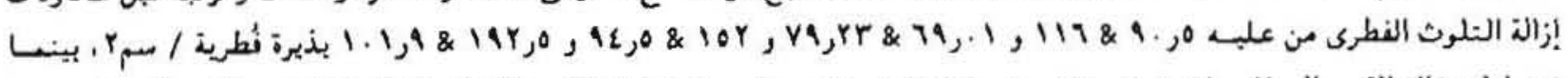
ثضا لت تلك التبم إلى .

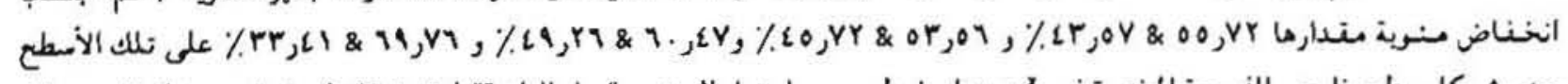

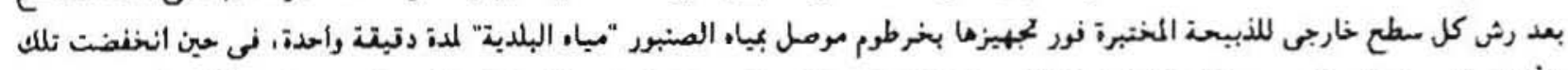

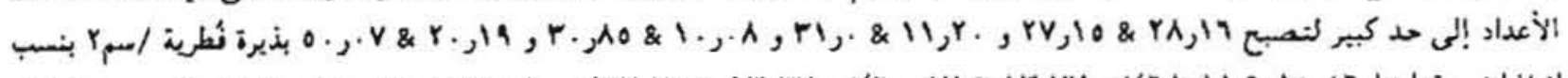

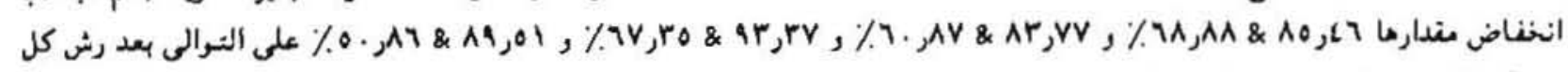

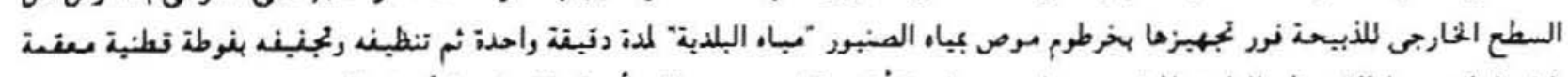

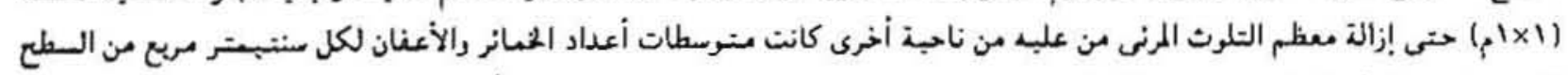

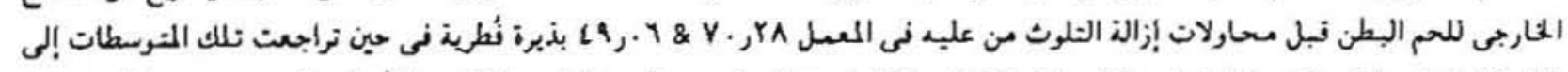
اليزروك

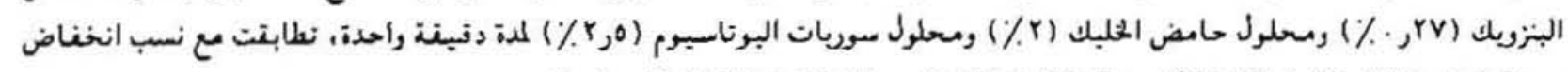
منرية مقدارها

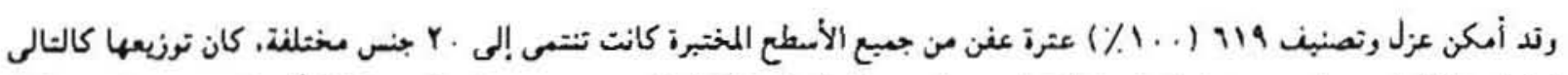

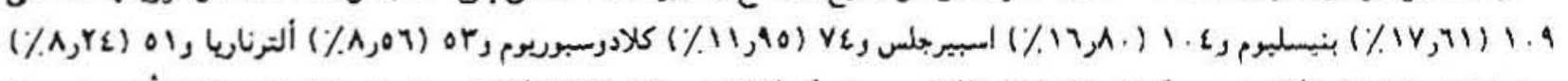

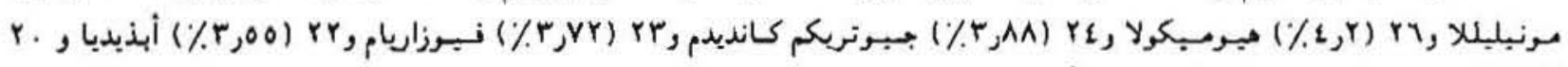

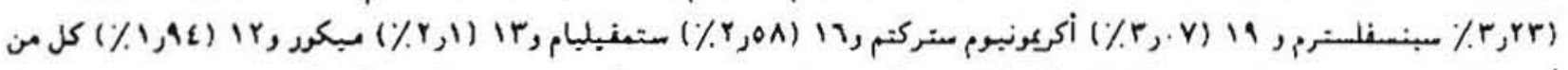

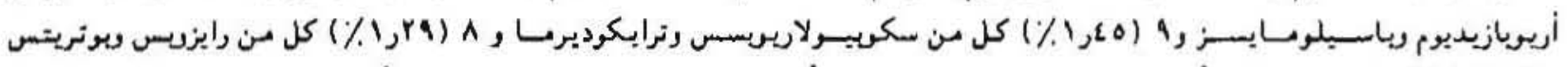

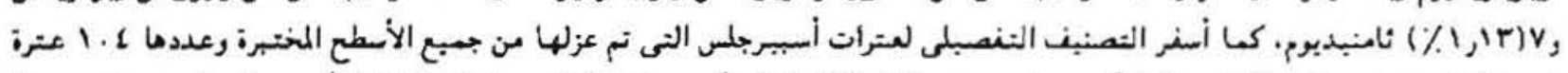

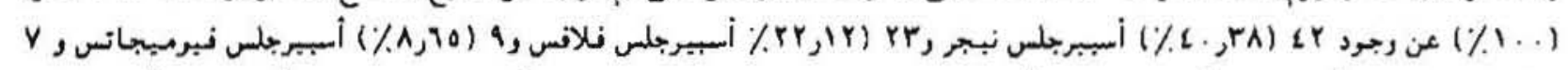

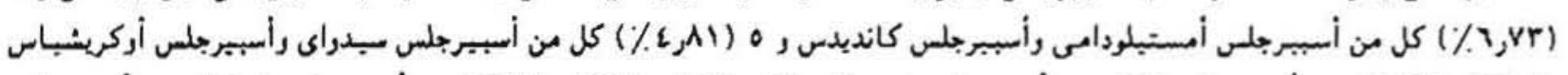

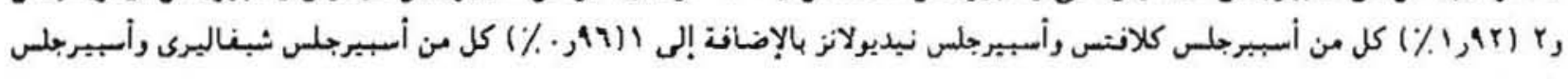
ونتباى. 